\title{
Development and Quality Evaluation of Edible Plate
}

\author{
Sangita Sood*, Deepshikha \\ Department of FSNAT, CSKHPAU, Palampur-176062, India
}

\begin{abstract}
*Corresponding Author: Sangita Sood, Department of FSNAT, CSKHPAU, Palampur-176062, India, Email: sangitasood@rediffmail.com
\end{abstract}

\begin{abstract}
Edible plate is a ready to eat product that can be eaten without any further preparation. In this study edible plate is made up by using sorghum and rice flour. Dough was made by using spinach juice instead of water not only to impart attractive colour to the product but also to improve nutritional value. As spinach juice contained carotenoids and flavonoids as $4.82 \mathrm{mg} / 100 \mathrm{~g}$ and 0.82 per cent respectively. The recipe was standardized by using various blends of sorghum and rice flour. The final product was made in the ratio of 50:50 of sorghum and rice flour. Chemical parameters viz. moisture, ash, protein and fat content are estimated at 2.57, 1.60, 4.81 and 1.72 per cent respectively. The product was evaluated for proximate, nutritional and phyto-chemicals. The energy and starch contents in the edible plate are calculated as 343.4 Kcals and 4.25 per cent. Consumers' acceptability was also assessed by offering to a panel of judges and over score was bagged as 7.20 on ten point Hedonic scale.
\end{abstract}

Keywords: Edible plate, Spinach juice, Sorghum flour, Rice flour

\section{INTRODUCTION}

With increased urbanisation women folks are stepping out for jobs, they are having hardly any time for cooking and washing utensils. The demand for plastic containers is increasing over the past few decades. The use of which is harmful to human body because of presence of toxins and carcinogens. This is also a matter of great concern, now days that the environment impact caused by the excessive quantity of non degradable waste materials discarded every day. Edible cutlery is trending way to overcome all these problems.

This edible cutlery can be called as ready to eat because these do not need any further preparation. Edible cutlery can be used as utensils and also solid, semi-solids things can be served in it. They do not get soggy quickly. These are environment friendly as they can easily discarded and eaten by animals. They can be eaten without serving anything in it. Edible cutlery can be provided during wars, disaster prone areas where scarcity of food due to lack of resources.

Millets are considered as crop of food security because of their sustainability in adverse agroclimatic conditions (Ushakumari et al. 2004). Moreover, they are not only rich in macronutrients but are also concentrated source of micro-nutrients. Sorghum (Jawar) and other millets provide an important source for dietary calories and protein for approximately one billion people in the semiarid regions of the world (Linda et al. 2006).

Rice is one of the leading food crops of the world and is a staple food of over approximately one-half of the world population (Singh et al. 2005). Rice production in China has a spectacular increase in the recent years and is approximately 30 per cent of the total rice production of the world (Wu and Zhou 2007). In Himachal rice is eaten as a staple food item. Keeping in mind the nutritional importance of these crops, it was attempted to develop edible plate by blending these two important crops. Spinach was added not only to add nutritional value but also to make it more attracted. The prepared cutlery was evaluated for chemical as well nutritional constituents. Consumers' acceptance is also assessed.

\section{Materials And Methods}

The present study was conducted in the Department of Food Science, Nutrition and Technology, College of Home Science, CSK HPKV, Palampur.

\subsection{Procurement of Samples}

Raw material was procured from local market (sorghum and rice flour) and spinach from the 
University farm for the preparation/formulation of edible container. Preliminary work was done to standardize the recipe for edible plate by using different blends of rice and sorghum. The prepared samples were offered to judges to know best level of proportion of these blends.

\subsection{Extraction Of Spinach Juice}

The spinach was procured, washed and juice was extracted by pressing the blanched material. Blanching technique was standardised with $20 \mathrm{~g}$ of spinach. Sufficient amount of water is added just to immerse the spinach leaves completely in it. Blanching was done for different time intervals i.e. 1, 2 and 3 minutes to get the better colour retention in the extracted juice. Unit operations used for the development of edible plate explained below:

\subsubsection{Unit operation for Development of Edible Plate}

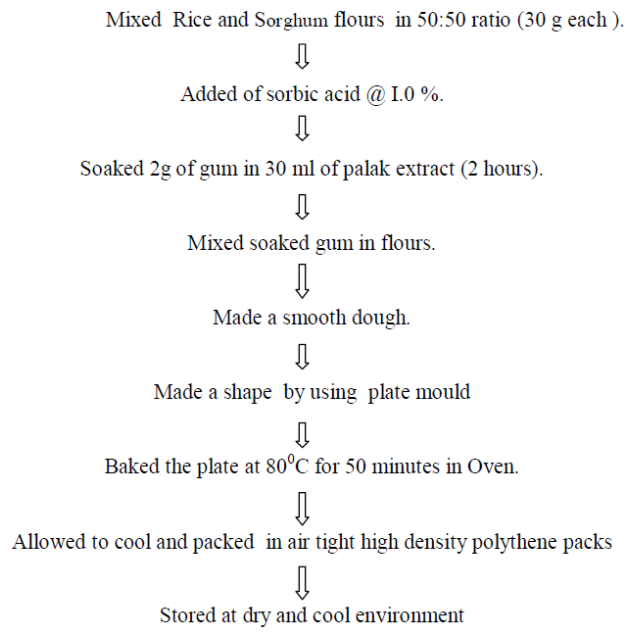

\subsection{Chemical Evaluation}

Raw materials as well as final product were evaluated for chemical as well nutritional constituents by using standard methods. The observations were made in triplicate to reduce the experimental error. Moisture content in the sample was determined by following Oven drying method by following AOAC, 2010. Crude protein, crude fat and crude fibre were estimated by using the procedure as laid down in AOAC, 2010. Dietary fibre and energy was determined by using the procedure explained by Van soest and wine, 1967 and O'shea and Mayure, 1962. Clegg, 1956 method was used for estimating starch. Two photochemical namely caretonides and flavonoids were determined by following the methods given by Rangana 2006 and Boham kocipia 1994.

\subsection{Organoleptic Evaluation}

Edible plates were evaluated for different sensory attributes by a panel of ten judges. Each panel members was asked to evaluate the product with respect to color, flour, taste and texture by following the method as suggested by Gould (1978).

\section{RESULTS AND DISCUSSION}

\subsection{Chemical Evaluation}

The result of the chemical evaluation is presented in Table 1. Table shows that per cent moisture, total ash, crude fat, crude fiber and crude protein in sorghum flour was calculated as 10.27, 2.57, 2.19, 0.70 and 9.45. Whereas, the values for $\mathrm{ADF}, \mathrm{NDF}$ and starch in the same samples were estimated at $7.15,5.30$ and 71.33 percent. Jaybhaye et.al. (2014) reported the per cent protein, ash, fat, crude protein and crude fiber in sorghum flour as 10.40,1.60, 3.10 and 2.00 respectively. Similarly Boniface et al. (2011) found that the protein content, fat, ash and crude fibre in untreated sorghum flour was $19.77,7.48,4.82$ and 4.82 respectively. This gives credence to the present findings.

Table1. Chemical Parameters in Raw Material

\begin{tabular}{|l|l|l|l|l|l|l|l|l|l|}
\hline Samples & $\begin{array}{c}\text { Moisture } \\
(\boldsymbol{\%})\end{array}$ & $\begin{array}{c}\text { Ash } \\
(\boldsymbol{\%})\end{array}$ & $\begin{array}{c}\text { Crude } \\
\text { Fat(\%) }\end{array}$ & $\begin{array}{c}\text { Crude } \\
\text { Fiber(\%) }\end{array}$ & $\begin{array}{c}\text { Crude } \\
\text { Protein } \\
(\boldsymbol{\%})\end{array}$ & $\begin{array}{c}\text { Dietary fiber } \\
\text { ADF } \\
(\boldsymbol{\%})\end{array}$ & $\begin{array}{c}\text { Energy } \\
\text { NDF } \\
(\boldsymbol{\%})\end{array}$ & Kcals & Starch(\%) \\
\hline Sorghum & 10.27 & 2.57 & 2.19 & 0.70 & 9.45 & 5.30 & 7.15 & 353.33 & 71.23 \\
\hline Rice & 14.70 & 2.35 & 1.89 & 0.64 & 6.82 & 0.25 & 0.67 & 340.00 & 79.43 \\
\hline Spinach & 93.73 & 1.89 & 0.60 & 0.59 & 1.54 & 11.46 & 29.63 & 25.00 & Nil \\
\hline
\end{tabular}

In case of rice flour the values for the same constituents were calculated as $14.70,2.35$, $1.89,0.64$ and 6.82 per cent respectively. The calorific value in rice flour was obtained as $349.00 \mathrm{Kcals}$. In rice, the values for ADF, NDF and starch were established at $0.67,0.25$ and 79.43 per cent. ADF and NDF in spinach powder was found to be on the higher ebb ie. 29.63 and 11.46 per cent and starch was not found. Per cent moisture, total ash, crude fat, crude fiber and crude protein in the spinach powder water were obtained as $93.74,1.89$, $0.60,0.59$ and 1.54 respectively. The values for fat, fiber and proteins were in the present studies comparitatively less because of variation in varietal, agro climatic and cultural practices. When the work done by the same team is compared for the same constituents, a similar 
trend was obtained. Chandra et al. (2013) reported that the moisture content in rice flour was 11.22 per cent. Whereas jaybhaye et al. (2014) reported that in rice flour the protein, fat, ash, crude fibre and energy were 7.90, 2.70, $1.30, \quad 1.00$ and 362.00 respectively. The difference might be due to the variations in agro climatic conditions and varietal difference.

\subsection{Phyto-Chemicals in the Sample}

In the test samples the phyto-chemicals were also estimated and the results are depicted in Table2. Perusal of the same table shows that sorghum, rice and spinach contained 0.61, 0.09 and $4.82 \mathrm{mg} / 100 \mathrm{~g}$ carotenoid content. Whereas, in the same samples the flavonoids were estimated at $0.76,0.48$ and 0.82 per cent respectively.

Table2. Phyto-Chemicals in Raw Materials

\begin{tabular}{|l|l|l|}
\hline \multicolumn{1}{|c|}{ Samples } & Carotenoids(mg/100g) & $\begin{array}{c}\text { Flavonoid } \\
\text { S (\%) }\end{array}$ \\
\hline Sorghum & 0.612 & 0.76 \\
\hline Rice & 0.09 & 0.48 \\
\hline Spinach & 4.82 & 0.82 \\
\hline
\end{tabular}

\subsection{Evaluation of Edible plate}

This edible plate made of sorghum and rice flour by adding spinach juice as a colouring agent. Sorbic acid used as a anti-fungal agent. The developed product was evaluated for chemical, nutritional and organoleptic evaluation. Results thus obtained are discussed under their suitable tables.

\subsection{Chemical Evaluation of the Edible Plate}

As is evident from Table 3 the edible plate contained $2.57,1.60,1.72,4.81$ and 0.64 per cent moisture, ash, crude fat, crude protein and crude fibre respectively. The NDF and ADF were calculated as 3.40 and 1.64 per cent. Percentage of starch was 4.25 . The energy value was obtained as 343.40 Kcals per 100 gram of the sample.

Table3. Chemical Parameters of Edible Plate

\begin{tabular}{|c|c|c|}
\hline \multicolumn{2}{|c|}{ Moisture(\%) } & 2.57 \\
\hline \multicolumn{2}{|c|}{$\operatorname{Ash}(\%)$} & 1.60 \\
\hline \multicolumn{2}{|c|}{ Crude fat $(\%)$} & 1.72 \\
\hline \multicolumn{2}{|c|}{ Crude protein $(\%)$} & 4.81 \\
\hline \multicolumn{2}{|c|}{ Crude fiber $(\%)$} & 0.64 \\
\hline \multirow{2}{*}{$\begin{array}{l}\text { Dietary } \\
\text { fiber } \\
(\%)\end{array}$} & NDF & 3.40 \\
\hline & $\mathrm{ADF}$ & 1.64 \\
\hline \multicolumn{2}{|c|}{ Starch (\%) } & 4.25 \\
\hline \multicolumn{2}{|c|}{ Energy (Kcals) } & 343.40 \\
\hline
\end{tabular}

\subsection{Phyto-Chemicals of Plate}

Phyto- chemicals which are the bioactive non nutrient plant compounds in foods and linked to reductions in the risk of major chronic diseases. Flavonoid is known for its antioxidant and antiinflammatory health benefits, as well as its contribution of vibrant color to the foods while carotenoids provide health benefits in decreasing the risk of disease, particularly certain cancers and eye disease. Keeping in mind this significance, in the edible plate these two parameters were estimated and observed as $2.72(\%)$ and $0.64 \mathrm{mg} / 100 \mathrm{~g}$ respectively.

\begin{tabular}{|l|l|}
\hline Flavonoids (\%) & 2.72 \\
\hline Carotenoids(mg/100g) & 0.64 \\
\hline
\end{tabular}

\subsection{Organoleptic Evaluation of Edible Plate}

To assess the consumers' acceptability the organoleptic evaluation was done by 10 trained panellists and they were asked to evaluate the product in terms of color, taste, texture and overall. The plate bagged the scores for these parameters as 7.6,7.0,7.0 and 7.2 respectively.

\begin{tabular}{|l|l|}
\hline Color & 7.6 \\
\hline Taste & 7.0 \\
\hline Texture & 7.0 \\
\hline Overall accepetability & 7.2 \\
\hline
\end{tabular}

\section{REFERENCES}

[1] AOAC. 2010. Approved methods of association of official analytical chemist. $11^{\text {th }}$ edition, Washington, D.C.U.S.A. p 345

[2] Boham AB and Kocipia AC. 1994. Flavonoids and condensed tannins from leaves of haviian vaticulam and vicaly. Pacific science 48(1): 458463

[3] Chandra S and Samsher. 2014. Assessment of functional properties of different flours. African journal of agriculture 8(38): 4849-4852

[4] Clegg KM 1956, the application of the anthrone reagent to the estimation of starch in cereals. Journal of the science of food and agriculture $7: 44$

[5] Gould WA. 1978. Food quality assurance. The AVI publishing company Inc. West port, connecticut

[6] Jaybhaye RV, Pardeshi IL, Vengaiah PC and Srivastva PP. 2014. Processing and technology for millets based food products. Journal of ready to eat food 1(2): 32-48

[7] Jaybhaye RV, Pardeshi IL, Vengaiah PC and Srivastva PP. 2014. Processing and technology for millets based food products. Journal of ready to eat food $1(2)$ : $32-48$

[8] Linda D, lyold WR. 2006. Sorghum and millet phenols and antioxidants. Ceral quality 
laboratory, department of siol and crop science, texas $\mathrm{p} 239-241$

[9] O'shea JO and Maguire MP. 1962. Determination of calorific value of food stuff by chronic acid oxidation. Journal of science of food and agriculture 13:530-532

[10] Rangana. 2006. Handbook of analysic and quality control for fruits and vegetable products, $3^{\text {rd }}$ edition, tata mcgrew- hills publishing company limited new delhi, p 39
[11] Ushakumari SR, Shrikaantan L and Malleshi NG. 2004. The functional propertyies of popped, flaked, extruded and roller dreid foxtail millet. International journal of food science and technology 39: 907-915

[12] Van soest PJ and wine RH. 1967. Use of detergent in the analysis if fibrous foods, determination of plant cell wall constituents. Journal of association of official analytical chemistry 50:50

Citation: Sangita Sood \&Deepshikha. Development and Quality Evaluation of Edible Plate. ARC Journal of Nutrition and Growth. 2018; 4(2): 1-4. DOI: dx.doi.org/ 10.20431/2455-2550.0402001.

Copyright: (C) 2018 Authors. This is an open-access article distributed under the terms of the Creative Commons Attribution License, which permits unrestricted use, distribution, and reproduction in any medium, provided the original author and source are credited. 